\title{
MEMPERTIMBANGKAN KEMBALI HUBUNGAN ISLAM DAN ILMU PENGETAHUAN
}

\author{
Judul Buku : Islam dan Sains, Upaya Pengintegrasian Islam dan \\ Ilmu Pengetahuan di Indonesia \\ Penulis : Prof. Dr. Dede Rosyada, M.A. \\ Penerbit : RM Books Jakarta \\ Tahun : 2016 \\ I s I : 226 halaman
}

I S B N : 9786027930

Perjumpaan Ilmu Pengetahuan dan ajaran Islam melahirkan berbagai gagasan yang bertujuan memadukan atau menyelaraskan antara satu dengan lainnya. Dalam perjalanan perbincangan soal ini, terdapat dua pola harmonisasi hubungan Islam dan Ilmu Pengetahuan, yakni Islamisasi ilmu pengetahuan, integrasi keilmuan. Dalam hal ini, UIN Syarif Hidayatullah Jakarta memilih pola integrasi keilmuan. Pola terakhir diambil karena pola ini memungkinkan terciptanya interaksi dialogis berbagai macam ilmu pengetahuan, termasuk interaksi ilmu pengetahuan dan agama.

Buku Dede Rosyada ini mencoba mengambil bagian dalam perbincangan mengenai hubungan Islam dan sains tersebut. Namun, menurut Dede, diskursus tentang Islamisasi Pengetahuan sebenarnya sudah tidak terlalu signifikan untuk diangkat kembali. Hal itu, lanjut Dede, karena persoalan itu muncul semata karena teori-teori tentang berbagai ilmu empirik masuk ke dunia Islam dari dunia Barat yang sekuler, sehingga ada kecurigaan dari para sarjana Muslim bahwa teori-teori tersebut bisa sesat dan menyesatkan. Padahal pemahaman para sarjana Muslim tentang teori-teori pengetahuan serta kaitannya dengan ajaran Islam sudah kian maju.

Fokus yang cukup urgen untuk dicoba dibahas adalah di mana wilayah Islam pada struktur keilmuan, karena masih ada diskusi tentang apakah Islam itu hanya pada wilayah aksiologi, atau justru pada wilayah antologi.

Di masa kejayaan Islam terutama abad delapan sampai sepuluh Masehi, kaum Muslim begitu massif mengembangan ilmu pengetahuan, baik ilmu keislaman maupun ilmu pengetahuan rasional. Yang menarik menurut Dede, kemajuan sains tidak secepat 
pengembangan ilmu-ilmu keagamaan, seperti fiqih, ilmu kalam, filsafat dan tasawuf, yang sudah mulai dikembangkan sejak periode Dinasti Bani Umayyah (661-750 M).

Kendatipun demikian, para ilmuwan Muslim telah berhasil mengembangkan ilmu-ilmu empiris dan melahirkan karya-karya besar di bidang matematika, astronomi, fisika, kedokteran, kimia, dan lainnya sebagai hasil penelitian mereka. Dalam sejarah dikenal para ahli matematika Muslim antara lain Abu Yusuf Ya'qub bin Ishaq asSabbah al-Kindi (801-873 M) dan Muhammad bin Musa alKhawarizmi (780-850 M) yang hidup pada abad ke 8 dan $9 \mathrm{M}$. Kemudian dalam fisika kita mengenal tokoh-tokoh besar seperti Abu Ali Muhammad al-Hasan ibn al-Haitsam (965-1040 M), Abu Raihan al-Biruni (973-1048 M) dan lainnya. Lalu dalam Kimia dan Biologi, di masa Islam klasik lahir tokoh-tokoh besar seperti Abu Musa Jabir bin Hayyan (750-803 M), Abu Uthman Amr al-Bashri al-Jahiz (776-868 M) dan lainnya.

Sementara itu salah satu sains yang berkembang secara spektakuler adalah kedokteran. Pada abad kedelapan dan kesembilan Masehi kedokteran berkembang sangat pesat di dunia Islam, dengan berbagai tulisan yang sangat bermakna untuk kemajuan ilmu tersebut pada periode-periode sesudahnya. Tradisi pengobatan sebelumnya tidak memiliki dokumen sejarah tertulis sehingga tidak bisa diungkapkan, kecuali yang terilustrasikan Rasululllah dalam hadishadisnya seperti al-Harits bin Kaldah al-Tsaqafi (634-635 M) dan putranya bernama Nadr bin Harits bin Kaldah sebagai tabib terkenal di zaman Jahiliyah yang memberi layanan pada masyarakat di masa awal Islam.

Kajian-kajian tentang kedokteran kemudian berkembang pada generasi berikutnya, terutama setelah munculnya Abu Bakar Muhammad bin Zakaria al-Razi. Ia merupakan ilmuwan sekaligus dokter yang sangat besar jasanya terhadap ilmu kedokteran. Tidak hanya memberikan layanan terhadap masyarakat dalam profesinya sebagai dokter dengan menjadi dokter kepala di sebuah rumah sakit Baghdad, al-Razi juga banyak mengembangkan penelitian dan penulisan buku-buku tentang kedokteran dan kimia. Berbagai teori kedokteran yang dilahirkan dan dikembangkannya menjadi rujukan para dokter yang mengembangkan ilmu kedokteran di Eropa.

Tokoh besar lainnya dalam kedokteran yang pernah berkembang di tengah masyarakat Muslim adalah Abu Ali al-Husayn 
bin Abdullah bin Sina atau dikenal sebagai Ibnu Sina (980-1037 M), Karya terbesar Ibn Sina berjudul al-Qanun fi al-Thib (Prinsip-prinsip Kedokteran) yang merupakan buku rujukan di berbagai fakultas kedokteran di belahn Eropa dan belahan dunia lainnya selama tujuh abad. Komitmennya terhadap ilmu dan penelitian menuntun Ibnu Sina untuk senantiasa mencatat berbagai kasus yang ditemukannya serta terus menganalisis berbagai catatan temuannya untuk terus memperbaiki dan memperkuat teori-teorinya.

Al-Quran bukan kitab sains, juga bukan kitab yang berbicara teknologi. Al-Quran adalah kitab yang menyampaikan ajaran keagamaan, tetapi dalam penyampaian pesan-pesan ajaran tersebut, alQuran tetap menyimpan kemahaagungan berupa gaya bahasa yang sangat indah, sekaligus mengilustrasikan berbagai pesan sosial. Salah satu ilustrasinya adalah pengembangan sains dan teknologi yang menyatu dengan pesan-pesan etika dan teologis.

Kurang lebih itulah uraian bagian pertama buku ini. Selain tinjauan teoritis mengenai integrasi Islam dan Ilmu, bab pertama menguraikan sejarah kemajuan sains oleh ilmuwan Islam, diakhiri dengan pembelajaran sains di pesantren.ai

Pada bagian kedua buku Rektor UIN Jakarta ini mengambil judul model integrasi ilmu yang dikembangkan oleh UIN Jakarta. Namun model integrasi ilmu yang diuraikan dalam bab ini tidak menjelaskan bagaimana konsep, teori dan aplikasi yang ingin digagas UIN Jakarta. Dede hanya menyatakan:

Secara ideal, pengembangan berbagai disiplin ilmu umum dalam lingkungan UIN dan berinteraksi dengan ilmu-ilmu keagamaan, dikembangkan dengan tiga tujuan ideal yang menjadi dambaan bersama umat Islam Indonesia, yakni:

Pertama, kajian general science (natural science, social and humanity) dikembangkan dalam rangka memahami dan mengembangkan norma-norma keagamaan pada berbagai aspek kehidupan profesi dan sosial.

Kedua, kajian general science juga dikembangkan dalam rangka melahirkan teori, teknologi, bahkan instrumen yang dapat digunakan untuk mengoperasikan teori tersebut dalam berbagai sektor kehidupan yang secara paradigmatik berasal atau terinspirasi oleh teks suci doktrin keagamaan.

Ketiga, proses pendidikan yang dikembangkan untuk para mahasiswa yang megambil keahlian diluar bidang keagamaan , 
dikembangkan dalam rangka melahirkan tenaga terampil dan tenaga ahli yang akan mengimplementasikan teori, teknologi, dan instrumen ilmu dalam berbagai lapangan kehidupan profesi dan sosial, sehingga benar-benar terwujud idealitas, karena agama merupakan rahmat bagi seluruh kehidupan umat manusia.

Pada bagian akhir buku karya mantan direktur Pendidikan Tinggi Islam Kemenag ini menguraikan ikhtiar perlunya mengokohkan Islam moderat. Bagian ini Dede menekankan UIN Jakarta yang dipimpinnya sebagai lembaga pendidikan tinggi Islam untuk mendidik para mahasiswa menjadi Muslim yang memiliki pandangan, sikap dan tindakan keagamaan yang produktif ujtuk menjadi bagian dalam proses pembangunan bangsa ke depan. Salah satu kebijakan penting dalam pengembangan kampus, lanjut mantan Dekan Fakulktas Tarbiyah UIN Jakarta ini, adalah membina sikap dan pandangan para mahasiswa untuk menjadi sarjana yang moderat, inklusif, pluralis, dan toleran terhadap keragaman.

Meskipun demikian, Dede menegaskan, UIN Jakarta tidak mengajarkan para mahasiswa kebenaran ganda, yakni semua agama itu benar, dan boleh beramal dengan agama yang menjadi pilihannya secara bergantian. Ia melanjutkan, hanya satu kebenaran agama, dengan tetap menghormati agama yang dianut masyarakat beragama lainnya.

Buku yang disusun dari berbagai makalah untuk kepentingan momen akademis ilmiah ini penting dibaca oleh para warga kampus dan juga masyarakat mengingat urgensinya bagi pemahaman dan cara pandang kita dalam merespon berbagai perkembangan dan dinamika keummatan di tengah umat Islam menghadapi berbagai tantangan kehidupan yang makin lama makin besar.

(Didin Saepudin) 